\title{
Cutaneous metastases in non-small cell lung cancer
}

\author{
Robert Brian McGrath, ${ }^{1}$ Shane Patrick Flood, ${ }^{1}$ Ruth Casey $^{2}$
}

${ }^{1}$ Department of Respiratory Medicine, Galway University Hospitals, Galway, Ireland ${ }^{2}$ Department of Medicine, Galway University Hospitals, Galway, Ireland

\section{Correspondence to} Dr Robert Brian McGrath, robert.mcgrath@hse.ie

Accepted 8 September 2014
CrossMark

To cite: McGrath RB, Flood SP, Casey R. BMJ Case Rep Published online: [please include Day Month Year] doi:10.1136/bcr-2014205752

\section{DESCRIPTION}

A 61-year-old man presented with right pleuritic chest pain, $15 \mathrm{~kg}$ weight loss, shortness of breath and two painful scalp lesions (figure 1). He had a 40 -pack a year smoking history with exposure to asbestos. Thoracocentesis of a right pleural effusion demonstrated atypical cytology. Staging CT showed osseous metastases and right lung apical scarring. Bone and scalp biopsies revealed poorly differentiated squamous cell carcinoma and marrow infiltration by poorly differentiated tumour, respectively, both suggestive of lung primary. Pleural biopsy confirmed stage IV adenosquamous lung carcinoma. The patient's course post-thoracoscopy was complicated by pneumothorax, subcutaneous emphysaema and a malpositioned emergent thoracostomy tube with resultant haemoptysis. Palliative radiotherapy of cutaneous metastases was performed. Further adjuvant treatment was postponed due to iatrogenic decline in functional status, highlighting the value of less invasive procedures, such as skin biopsy, in the evaluation of metastatic processes of unknown primary.

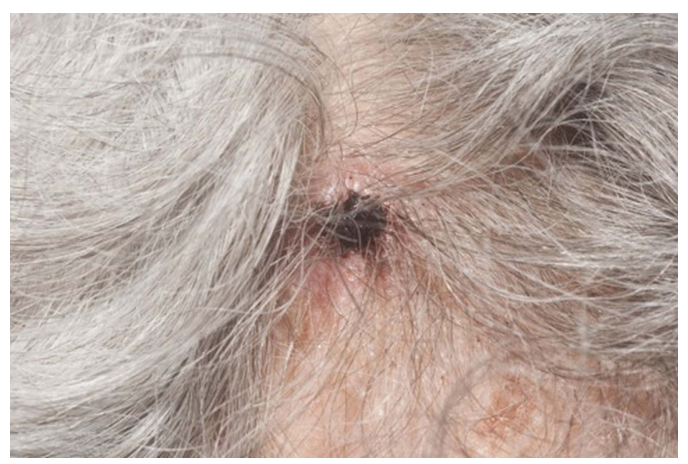

Figure 1 A $1 \mathrm{~cm}$ right frontoparietal, nodular, symmetrical, erythematous, tender, ulcerated, hard, fixed, cutaneous lesion.
Cutaneous metastases occur in 1-12\% of lung cancers. Pathogenesis is by lymphovascular invasion, with poor differentiation and upper lobe tumours increasing the risk of metastasis. Histology most commonly shows adenocarcinoma, then squamous/small-cell, followed by large-cell carcinoma. Lesions present with or before the primary in $20-60 \%$ of cases, can be single or multiple and are usually painless. ${ }^{1}$ Common sites include chest, back, head and neck. Treatment modalities include surgery, chemotherapy and radiotherapy, and treatment varies based on prognosis and symptoms. ${ }^{1}{ }^{2}$ Non-resectability, small-cell histology and multiple/ distant metastases confer a poor prognosis.

\section{Learning points}

- Cutaneous metastases should be suspected in those with suspicious skin lesions and presentation suggestive of a malignancy.

- Diagnosis of an unknown primary malignancy can be hazardous, impacting functional status and subsequent treatment. Consideration should be given to obtaining biopsies from the safest possible site first.

Contributors RBM and SPF were involved in acquiring the history from the patient, chart review, review of investigation results, literature review, writing and editing of the article. RC contributed significantly to the editing of the article.

\section{Competing interests None.}

Patient consent Obtained.

Provenance and peer review Not commissioned; externally pee reviewed.

\section{REFERENCES}

1 Mollet TW, Garcia CA, Koester G. Skin metastases from lung cancer. Dermatol Online J 2009;15:1.

2 Schwartz RA. Cutaneous metastatic disease. J Am Acad Dermatol 1995:33(2 Pt 1):161-82; quiz 183-6.

Copyright 2014 BMJ Publishing Group. All rights reserved. For permission to reuse any of this content visit http://group.bmj.com/group/rights-licensing/permissions.

BMJ Case Report Fellows may re-use this article for personal use and teaching without any further permission.

Become a Fellow of BMJ Case Reports today and you can:

- Submit as many cases as you like

- Enjoy fast sympathetic peer review and rapid publication of accepted articles

- Access all the published articles

- Re-use any of the published material for personal use and teaching without further permission

For information on Institutional Fellowships contact consortiasales@bmjgroup.com

Visit casereports.bmj.com for more articles like this and to become a Fellow 